\title{
Fungicidal effect of silver nanoparticles on toxigenic fungi in cocoa
}

\author{
Raquel Villamizar-Gallardo(1), Johann Faccelo Osma Cruz $^{(2)}$ and Oscar Orlando Ortíz-Rodriguez ${ }^{(3)}$
}

\begin{abstract}
(1)Universidad de Pamplona (Unipamplona), Departamento de Microbiología, Grupo de Investigación en Nanotecnología y Gestión Sostenible (Nanosost-UP), Km 1, Vía Bucaramanga, Campus Universitario, Pamplona, Norte de Santander, Colombia. E-mail: raqvillamizar@unipamplona.edu.co (2)Universidad de los Andes, Departamento de Ingeniería Eléctrica y Electrónica, Centro de Microelectrónica, Carrera 1 Este, no 19A-40, Edificio Mario Laserna, Bogotá, Colombia. E-mail: jf.osma43@uniandes.edu.co (3)Unipamplona, Departamento de Ingeniería Industrial, Facultad de Ingenierías y Arquitectura, Pamplona, Norte de Santander, Colombia. E-mail: oscarortiz@unipamplona.edu.co
\end{abstract}

\begin{abstract}
The objective of this work was to evaluate the microbicidal effect of silver nanoparticles (AgNPs) on potentially toxigenic fungi affecting cocoa (Theobroma cacao) crops. These fungi, isolated from diseased cocoa pods, were characterized phenotypically and genotypically. The microbicidal effect was assessed by measuring radial mycelial growth, in synthetic culture media, and at different AgNP concentrations in plant tissues. The inhibition effect was monitored in Petri dishes, and changes in fungal structures were observed through scanning electron microscopy. Two potentially toxigenic fungi were highly prevalent: Aspergillus flavus and Fusarium solani. The inhibition assays, performed in liquid and solid synthetic culture media, showed that AgNPs did not significantly affect the growth of these fungi, even at the highest concentration $(100 \mathrm{ppm})$. By contrast, they showed a positive inhibitory effect in plant tissues, especially in the cortex, when infected with $A$. flavus, in which an $80 \mathrm{ppm}$ dose completely inhibited fungal growth. However, once fungi have managed to penetrate inside the pods, their growth is unavoidable, and AgNP effect is reduced. On F. solani, the studied nanomaterial only induced some texture and pigmentation changes. The microbicidal effect of chemically synthesized silver nanoparticles is greater in plant tissues than in culture media.
\end{abstract}

Index terms: Aspergillus flavus, Fusarium solani, Theobroma cacao, alternative control, agri-food nanotechnology, ochratoxin A.

\section{Efeito fungicida de nanopartículas de prata em fungos toxigênicos em cacaueiro}

Resumo - O objetivo deste trabalho foi avaliar o efeito microbicida de nanopartículas de prata (AgNPs) em fungos potencialmente toxigênicos que afetam a cultura do cacau (Theobroma cacao). Esses fungos, isolados de frutos doentes, foram caracterizados fenotípica e genotipicamente. O efeito microbicida foi avaliado pela medição do crescimento radial do micélio, em meios de cultura sintéticos, e em diferentes concentrações de AgNPs nos tecidos vegetais. O efeito inibitório foi monitorado em placas de Petri, e as mudanças nas estruturas fúngicas foram observadas por meio de microscopia eletrônica de varredura. Dois fungos potencialmente toxigênicos foram altamente prevalentes: Aspergillus flavus e Fusarium solani. Os ensaios de inibição, realizados em meios sintéticos líquidos e sólidos, mostraram que as AgNPs não afetaram significativamente o crescimento desses fungos, mesmo à concentração mais elevada (100 ppm). Em contraste, elas produziram efeito inibidor positivo nos tecidos vegetais, especialmente no córtex infectado com $A$. flavus, em que uma dose de $80 \mathrm{ppm}$ inibiu totalmente o crescimento do fungo. No entanto, uma vez que os fungos tenham conseguido penetrar no interior dos frutos, seu crescimento é inevitável, e o efeito das AgNPs é reduzido. Em F. solani, o nanomaterial estudado apenas induziu algumas alterações de textura e pigmentação. $\mathrm{O}$ efeito microbicida das nanopartículas de prata sintetizadas quimicamente é maior nos tecidos das plantas do que no meio de cultura.

Termos para indexação: Aspergillus flavus, Fusarium solani, Theobroma cacao, controle alternativo, nanotecnologia agroalimentar, ocratoxina A.

\section{Introduction}

The Global Cocoa Agenda calls for a knowledgegenerating strategy aimed at conciliating productivity, technological innovation, and sustainability within the cocoa value chain. Cocoa (Theobroma cacao L.) world production reached five million tons in 2012 (Ortiz-Rodrigues et al., 2015). Currently, Colombia is the fourth cocoa producer in Latin America, after Brazil, Ecuador, and the Dominican Republic. In 2012, the cultivated area with cocoa in Colombia was about $158,000 \mathrm{ha}$, with a productivity of $460 \mathrm{~kg} \mathrm{ha}^{-1}$, which is 
certainly low, in comparison to that of Ivory Coast, the first producer worldwide, with $700 \mathrm{~kg} \mathrm{ha}^{-1}$ (Ortiz et al., 2014; Martínez-Ángel et al., 2015).

Cocoa production has been considerably affected by fungal diseases because pod fermentation activity is favored not only by specific $\mathrm{pH}$ and moisture conditions, but also by the positive feedback effect of the organic acids it produces. Moreover, the main problem associated with the presence of filamentous fungi in cocoa is the risk of mycotoxin production, which is likely to affect consumer health (Copetti et al., 2014). Chocolate has been reported to contribute with about $6 \%$ of the total dietary exposure to ochratoxin A, but mycotoxin levels in cocoa and chocolate are usually very low. However, since its detection methods are expensive and labor demanding, the Codex Alimentarius Commission (2013) has recommended keeping cocoa plantations as free of mould infection as possible.

Conventional control mechanisms involve good cropping practices, sometimes combined with the use of fungicides. The first method is easy to apply, but besides being labor demanding, its economic feasibility depends on elevated cocoa market prizes (Hanada et al., 2009). Although fungicides protect plants from pathogen attacks, they can have deleterious effects on the fly Forcipomyia sp., which pollinates cocoa flowers (FAO, 2012). Biological control is currently in use as an environmentally friendly and easy-to-apply control tool of phytopathogens (Cuervo-Parra et al., 2011). Yet, it presents certain difficulties, such as high specificity between biocontrollers and pathogens (Krauss et al., 2013), the need to adapt the controller to soil and climate conditions of the crop, and even resistance on the part of the pathogens (Mbarga et al., 2014). This has made it necessary to explore nonconventional control alternatives.

Nanotechnology is an important tool in modern agriculture, to the point that agri-food nanotechnology oriented to the sustainable production of human and animal food is likely to become one of the most profitable fields in this area in the coming future, especially in developing countries (Ranjan et al., 2014). Silver nanoparticles (AgNPs) are one of the most frequently used pesticide nanomaterials. They have received special attention for their low volatility, elevated stability, and broad antimicrobial activity (Pulit et al., 2013). These materials have been used successfully to inhibit the growth of phytopathogenic fungi on grasses and on cucumber, rice (Krishnaraj et al., 2012), and timber crops (Nasrollahi et al., 2011).

This endeavor is framed in a broader exploration of new alternatives for the control of phytopathogens that hinder the sustainability of this crop type.

The objective of this work was to evaluate the microbicidal effect of silver nanoparticles (AgNPs) on potentially toxigenic fungi affecting cocoa (Theobroma cacao) crops.

\section{Materials and Methods}

Silver nanoparticles Biopure-AgNP (NanoComposix, San Diego, CA, USA) at $1,000 \mathrm{ppm}\left(1.8 \times 10^{14}\right.$ particles $\mathrm{mL}^{-1}$ ) initial concentration, $9.27 \mathrm{mmol} \mathrm{L} \mathrm{L}^{-1}$ atomic molarity, spherical morphology, and $10 \mathrm{~nm}$ diameter were used as inhibitory material. This colloidal AgNP was diluted in sterile distilled water at room temperature $\left(22^{\circ} \mathrm{C}\right)$, in order to obtain suspensions at concentrations from 50 to $100 \mathrm{ppm}$. All suspensions were stored at $4{ }^{\circ} \mathrm{C}$, in the dark, until application.

Twenty diseased cocoa pods were selected from farms located in the municipalities of Chinácota and El Zulia, in the Department of Norte de Santander, Colombia, at altitudes from 220 to $1,200 \mathrm{~m}$, temperatures between 22 and $30^{\circ} \mathrm{C}$, and relative humidity from 63 to $86 \%$. The farms were selected from the list of associates of the National Federation of Cocoa Growers of Norte de Santander. Different biological materials - clones and hybrids - were sampled from cocoa pods with symptoms such as: deformations; yellow halos; and chocolate colored stains with well-defined borders, or cream colored powder (Phillips-Mora et al., 2007). The pods were wrapped in plastic sheets, labeled, and transported in boxes to the laboratory for experimentation.

Potentially toxigenic fungi were obtained from the cocoa pods. Spores contained in the outer pod cortexes were directly plated on potato-dextroseagar (PDA), modified with cocoa pod cortex extract and chloramphenicol (PDA-CC). Pure cultures were obtained from the heterogeneous ones, which were morphologically and molecularly characterized.

Morphological characterization followed a methodology modified from Ab Majid et al. (2015). Reproductive structures (spores), hyphal types, and the presence of septa were observed with lactophenol blue staining. The photographic record was obtained with an Eclipse 80i phase contrast optical microscope (Nikon, Japan). 
DNA was isolated by using an ultraclean microbial DNA isolation kit (Mo Bio Laboratories, Carlsbad, CA, USA), and prepared according to manufacturer specifications. The isolated DNA was amplified using two molecular markers, corresponding to the ITS region and the $\beta$-tubulin gene (Ab Majid et al., 2015) (Table 1). The amplified DNA was then sequenced by Macrogen (Seoul, Republic of Korea) and analyzed using Blast database.

AgNP inhibition assays were performed in different media: liquid and solid synthetic media, and cocoa pulp and cortex. The first assay was conducted on malt extract broth modified with AgNPs at 80, 85, 90, 95, and $100 \mathrm{ppm}$. Serocluster microdilution plates (Sterile, Corning Costar Corporation, New York, NY, USA) were inoculated with $200 \mu \mathrm{L}$ of the modified media and $100 \mu \mathrm{L}$ of each isolated fungus $\left(10^{7}\right.$ conidia $\left.\mathrm{mL}^{-1}\right)$. Five replicates of each assay were performed (CLSI, 2012).

A second assay was carried out on Petri dishes (60x15 mm) containing PDA-CC modified with AgNPs at 50, 70, 90, and $100 \mathrm{ppm}$. Each Petri dish was inoculated with $6 \mathrm{~mm}$ diameter agar plugs, each of which contained a young culture of the isolated phytopathogens. Radial growth of the fungal mycelium cultured at $25^{\circ} \mathrm{C}$ in PDA-CC was measured for a period of 18 days. A Petri dish without AgNP and inoculated with the pathogens was used as positive control, following the methodology adapted from Nasrollahi et al. (2011). All assays were repeated thrice.

The last assay was performed directly on cocoa pulp and cortex. Sterile, 24-well, TC Plates with lid (Cellstar, Sigma Aldrich, St. Louis, MO, USA) were used to place $0.5 \times 0.5 \mathrm{~cm}$ cocoa pulp and cortex pieces, which were previously sterilized under humid heat treatment $\left(121^{\circ} \mathrm{C}, 15 \mathrm{lb}\right.$-pressure, and $\left.20 \mathrm{~min}\right)$ and

Table 1. ITS region and $\beta$-tubulin genes employed as primers for the characterization of phytopathogenic fungi with toxigenic potential, isolated from cocoa (Theobroma cacao) diseased pods.

\begin{tabular}{lc}
\hline Molecular marker & Sequence \\
\hline & $\beta$-tub primer \\
Bt-Lev & GTG AAC TCC ATC TCG TCC ATA \\
& CAA CTG GGC TAA GGG TCA TT \\
\hline & ITS primer \\
PN3 & CCG TTG GTG AAC CAG CGG AGG GAT C \\
PN16 & TCC CTT TCA ACA ATT TCA CG \\
\hline
\end{tabular}

artificially spiked with $100 \mu \mathrm{L}$ of a $10^{7}$ conidia $\mathrm{mL}^{-1}$ suspension of spores. The plates were incubated at $25^{\circ} \mathrm{C}$ for 18 days. Three wells containing cocoa pulp and cortex infected with the corresponding phytopathogens were employed as positive controls, as adapted from Nasrollahi et al. (2011). Uninfected cocoa pulp and cortex were used as negative control. The inhibitory effect was determined macroscopically as the lowest AgNP dilution at which none of the tested phytopathogens was observed to grow after the 18day incubation period (Monteiro et al., 2011). Fungal structural changes after treatment with 50 ppm AgNP were monitored by scanning electron microscopy (SEM 0830 SEI, Korea).

\section{Results and Discussion}

Potentially mycotoxigenic genera such as Aspergillus and Fusarium were among the most commonly found pathogens in the studied diseased pods. Mounjouenpou et al. (2008) analyzed the proliferation of toxigenic fungi in cocoa crops, in Cameroon, and identified the same genera, including $A$. carbonarius and $A$. niger, which are potentially producers of ochratoxin A. Macro and microscopic characteristics of the phytopathogens that coincide with the previous report by Suárez Contreras \& Rangel Riaño (2013) are shown in Figure 1.

The molecular characterization allowed the determination of isolated strains of Aspergillus flavus and Fusarium solani. These two species are secondary pathogens which opportunistically complete fruit infection and degradation, by taking advantage of cocoa pod deterioration caused by primary pathogens of strong enzymatic activity (Cuervo-Parra et al., 2011). The presence of these fungi, however, is very significant to public health for their mycotoxigenic potential (Villamizar et al., 2011). Copetti et al. (2014) reported that frequent isolation of potentially toxigenic fungal species in cocoa is a cause for concern because they can produce aflatoxin and type A ochratoxin - both metabolites exhibit carcinogenic effects -, and have been found in cocoa beans and in manufactured and processed chocolate.

Inhibition assays using AgNPs in liquid media showed that $F$. solani and A. flavus grew at all tested concentrations, the latter proving to be the most resistant to the effect of AgNPs (Table 2).The inhibitory effect of AgNPs on these

Pesq. agropec. bras., Brasília, v.51, n.12, p.1929-1936, dez. 2016 DOI: 10.1590/S0100-204X2016001200003 
Morphological characteristics of cocoa phytopathogens
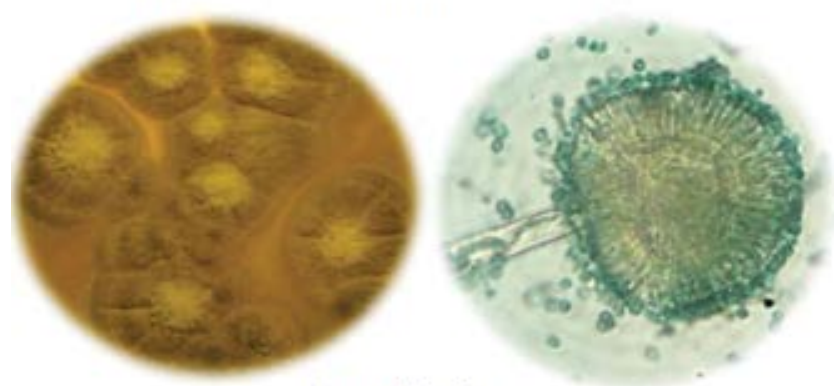

Aspergillus flavus

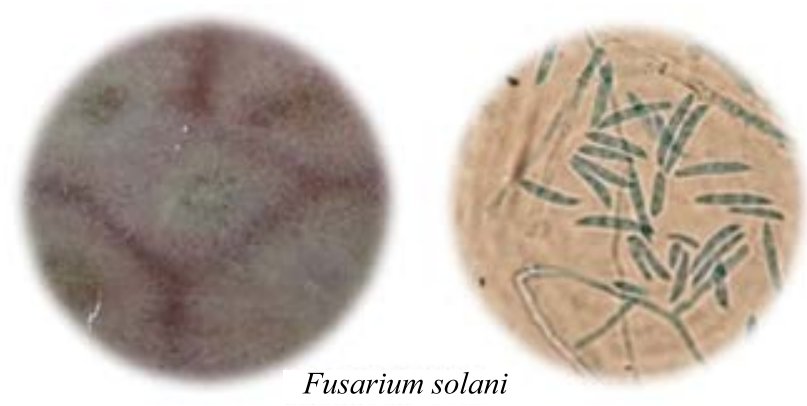

Figure 1. Macro and microscopic morphology of phytopathogenic fungi isolated from cocoa pod samples cultured in potato-dextrose-agar, modified with cocoa pod cortex extract and chloramphenicol (PDA-CC). Microscopic images were obtained from samples stained with lactophenol blue (100X). phytopathogens was also tested in the Petri dish assay with solid media (PDA-CC) (Figure 2), which covered a broader AgNP concentration range (50 to $100 \mathrm{ppm}$ ).

The antimicrobial properties of AgNP depend on several aspects, such as morphology, size, and concentration. The spherical nanoparticles with diameters below $10 \mathrm{~nm}$ employed in this assay can, in principle, facilitate the interaction with the target by electronic effects at the cellular level (Kim et al., 2007). However, only texture and pigmentation changes were induced in the tested phytopathogens.

Table 2. Inhibitory effect of different synthesized silver nanoparticles (AgNPs) concentrations on phytopathogenic fungi with toxigenic potential, isolated from cocoa (Theobroma cacao) diseased pods ${ }^{(1)}$.

\begin{tabular}{|c|c|c|c|c|c|c|c|c|c|c|}
\hline \multirow{2}{*}{$\begin{array}{l}\text { AgNP } \\
\text { concentration } \\
(\mathrm{ppm})\end{array}$} & \multicolumn{5}{|c|}{ Aspergillus flavus } & \multicolumn{5}{|c|}{ Fusarium solani } \\
\hline & R1 & $\mathrm{R} 2$ & R3 & $\mathrm{R} 4$ & R5 & $\mathrm{R} 1$ & $\mathrm{R} 2$ & R3 & R4 & R5 \\
\hline 80 & + & + & + & + & + & + & + & + & + & + \\
\hline 85 & + & + & + & + & + & + & + & + & + & + \\
\hline 90 & + & + & + & + & + & + & + & + & + & + \\
\hline 95 & + & + & + & + & + & + & + & + & - & - \\
\hline 100 & + & + & + & + & + & + & + & - & - & - \\
\hline
\end{tabular}

${ }^{(1)}$ The plus signal $(+)$ represents mycelial growth, while the minus signal (-) represents absence of mycelial growth. R1 to R5, replicates.

\section{Growth in PDA-CC modified with AgNP}
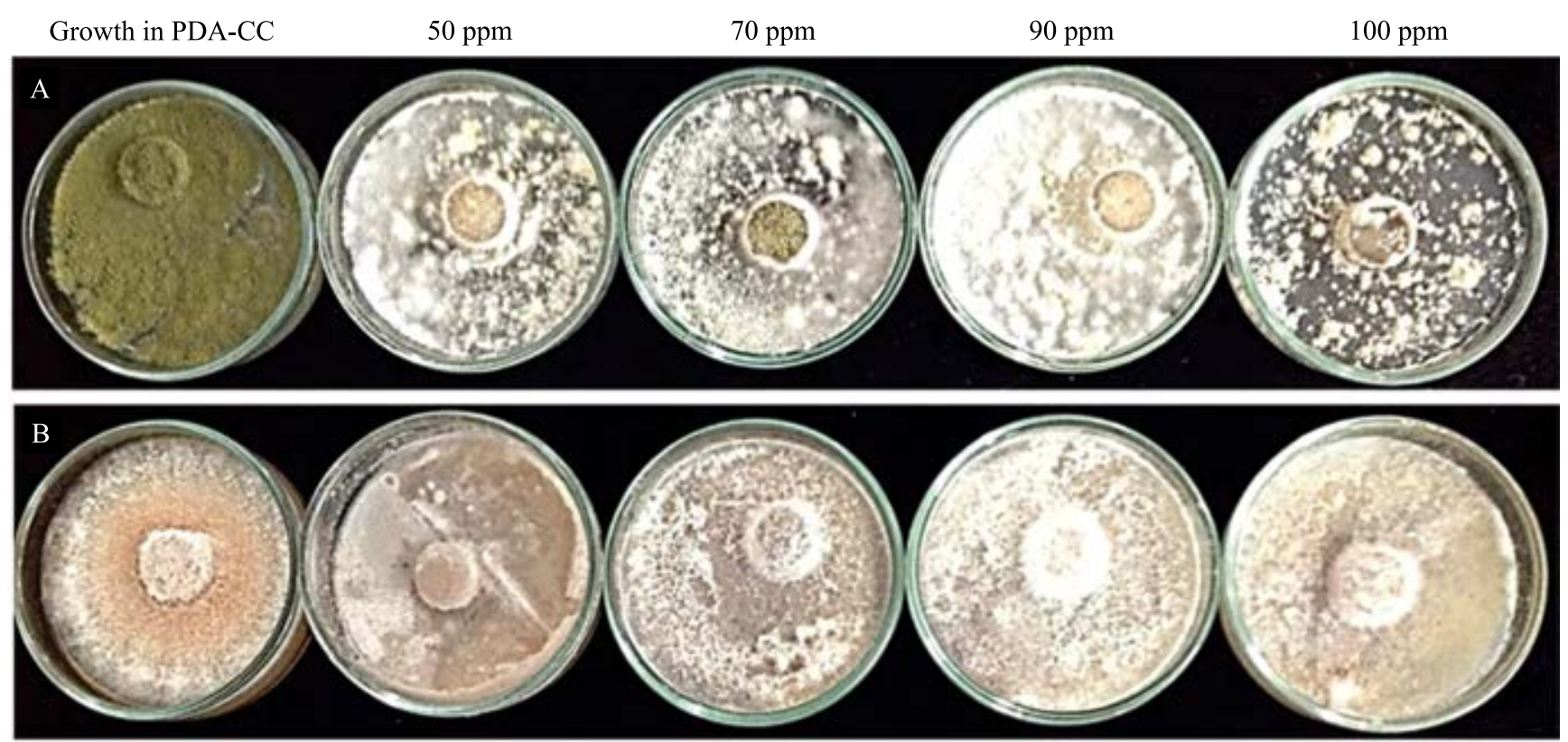

Figure 2. Effects of increasing synthesized silver nanoparticle (AgNP) concentrations on the macroscopic growth of potentially toxigenic cocoa fungi: A, Aspergillus flavus; and B, Fusarium solani. 
Mycelial growth, as measured on the Petri dishes, allowed to quantify the effect of AgNPs on the phytopathogens. Figure 3 shows the behavior of the two studied fungi as treated with or without AgNPs. The inhibitory effects were 5.32 and $3.29 \%$, for $F$. solani and A. flavus, respectively. Thus, no significant changes can be attributed to AgNPs.

Fungal resistance to silver nanoparticles has been attributed to their ability to produce secondary metabolites (Pulit et al., 2013). The main secondary metabolites are produced by the genus Aspergillus include polyketides (PKs), ribosomal and nonribosomal peptides (NRPs), and terpenoids (Andersen et al., 2013). However, this particular aspect should be studied in more details. Another explanation is based on the ability of certain $F$. solani and A. flavus strains to conduct extracellular synthesis of silver nanoparticles. This implies the presence of silver ion reducing enzymes and, consequently, some resistance to this metal (Alghuthaymi et al., 2015).

The assays carried out directly on cocoa fruit tissues (pulp and cortex) exhibited a slight growth of A. flavus on cortex. Thus, although an inhibitory effect was observed at $50 \mathrm{ppm}$, the minimum of 80 ppm AgNP concentration is required to completely inhibit fungal growth. This can be attributed to cortex composition, which offers a barrier to fungal penetration. By contrast, the fungi were able to grow at

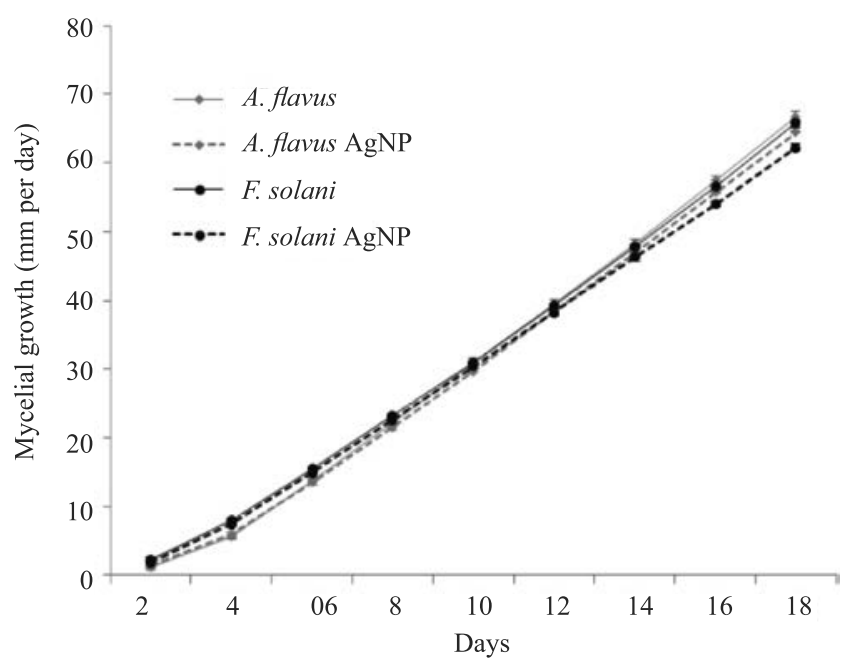

Figure 3. Mycelial growth of the phytopathogenic fungi Fusarium solani and Aspergillus flavus in potatodextrose-agar modified with cocoa pod cortex extract and chloramphenicol (PDA-CC), with or without synthesized silver nanoparticles (AgNPs). all concentrations in fruit pulp. This can be explained by the ability of some species to hydrolyze this tissue, thus producing acids that facilitate fungal growth through reduced $\mathrm{pH}$ (Copetti et al., 2014). In this tissue, even the highest concentrations (90-100 ppm) were not able to significantly affect fungal growth.

Fusarium solani was observed to be more resistant to AgNPs (Figure 4). Kasprowicz et al. (2010) reported that a nutrient-poor PDA medium modified with silver nanoparticles increased spore production. This phenomenon can be attributed to the fact that $F$. solani produces macroconidia which, by exhibiting complex multicellular organization (Harris, 2005), probably hinder the internal transport of silver nanoparticles, thus reducing their fungicidal effect.

The antimicrobial effect of nanoparticles is related to the concentration used and to the rate at which they are released. In the current work, this effect on culture media was found to be different from that observed in fruit tissues (cortex and pulp). This can be explained by the fact that synthetic culture media contain all the necessary nutrients for fungal growth, while plant tissues - particularly the cortex - offer a natural barrier to penetration into the pod. Therefore, silver nanoparticles are more likely to affect natural fungal reproduction. This is consistent with previously findings reported by Lamsal et al. (2011), who reported growth inhibition of Colletotrichum sp., the etiological agent of pepper anthracnose, by AgNP at $100 \mathrm{ppm}$ in PDA culture; whereas concentrations below $50 \mathrm{ppm}$ were enough to obtain the same results as in the field.

While metallic silver is inert, AgNPs are highly reactive due to the production of $\mathrm{Ag}+$ ions (Morones et al., 2005). In fungi, silver nanoparticles can cause structural changes in hyphae, cell wall deformations, membrane damages, and significant alterations in spore form and germination, depending on the fungicide concentration (Lamsal et al., 2011). In this research, the $50 \mathrm{ppm}$ treatments caused slight changes in mycelial structure, featured by hyphal deformation in F. solani, and by dwindling of reproductive structures, such as conidia, in A. flavus (Figure 5). However, these morphological changes did not affect the studied fungal life cycle.

Future research perspectives include exploring the use of biotechnologically synthesized silver nanoparticles or organic nanocomposites, whose superficial biological ligands probably enhance their fungicidal effect.

Pesq. agropec. bras., Brasília, v.51, n.12, p.1929-1936, dez. 2016 DOI: 10.1590/S0100-204X2016001200003 


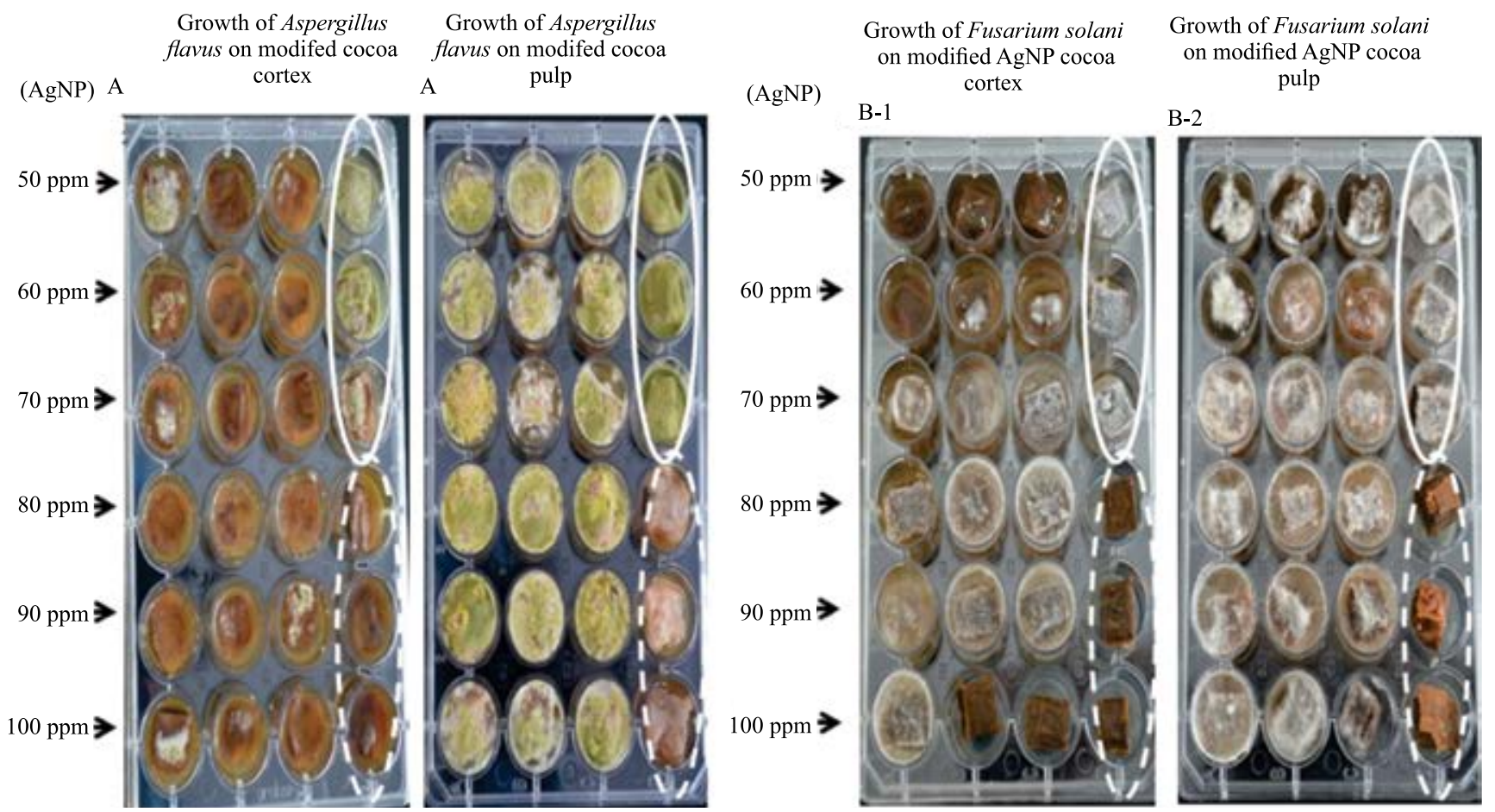

Figure 4. Microdilution assay using different synthesized silver nanoparticle (AgNP) concentrations against the tested phytopathogens: A, Aspergillus flavus; B, Fusarium solani. White circles enclose positive controls (without AgNP), while dotted circles enclose negative controls (only AgNP).
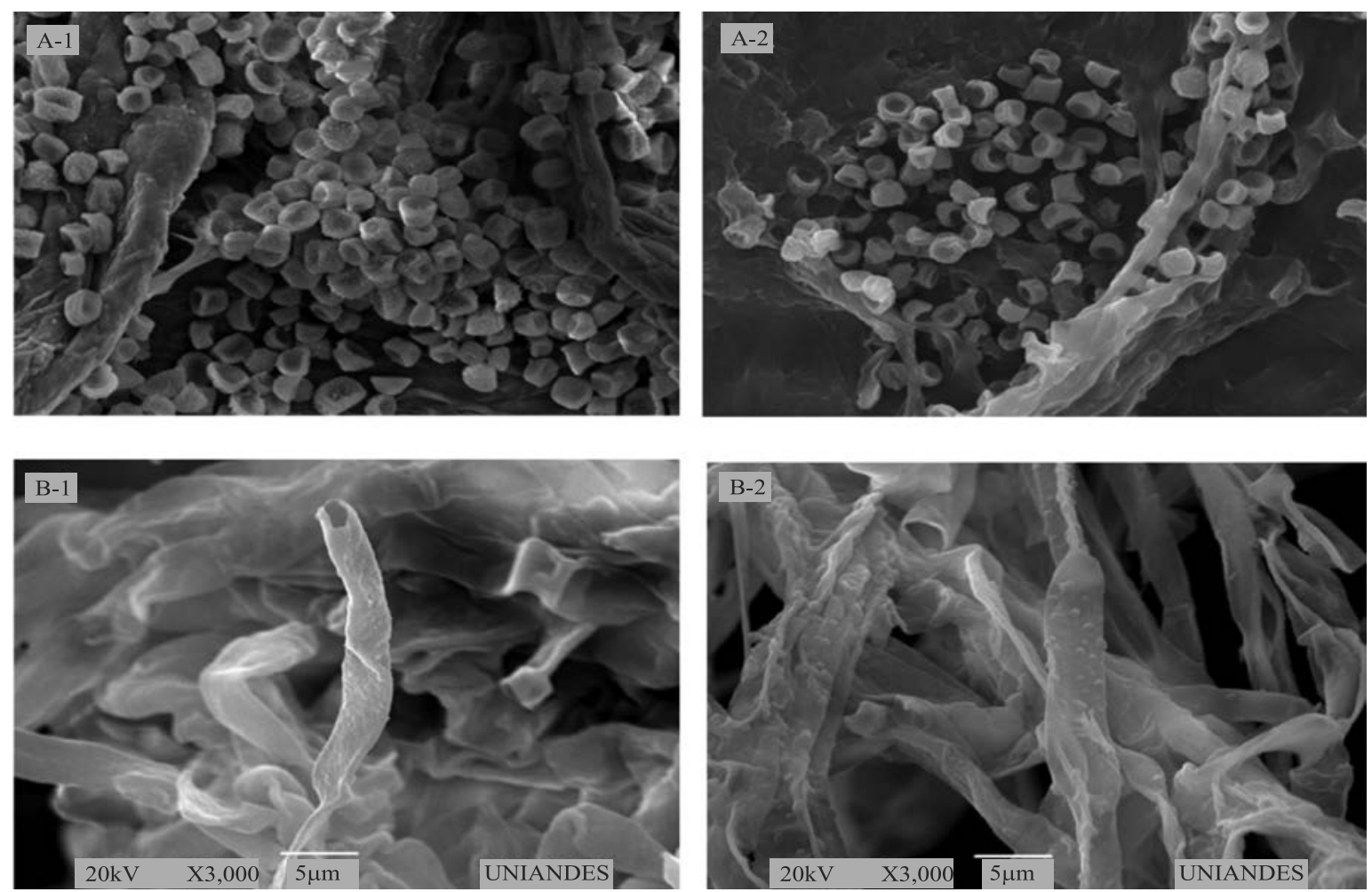

Figure 5. Effect of synthesized silver nanoparticle (AgNP) solutions on the fungal structure of: A1, Aspergillus flavus; A2, A. flavus treated with a 50 ppm AgNP; B1, Fusarium solani; and B2, F. solani treated with 50 ppm AgNP. 


\section{Conclusions}

1. The microbicidal effect of chemically synthesized silver nanoparticles (AgNPs) is greater in plant tissues than in culture media.

2. For Aspergillus flavus, an $80 \mathrm{ppm}$ concentration is enough to completely inhibit growth in cocoa cortex; however, once the pathogen manage to penetrate inside the pods, its growth is unavoidable, and AgNP effect in pulp tissue is further reduced.

3. For Fusarium solani, the AgNPs only cause texture and pigmentation changes, indicating resistance of this microorganism to the nanomaterial in question.

\section{Acknowledgments}

To the Colombian Administrative Department of Science, Technology, and Innovation (Colciencias), and to the Inter-American Development Bank, and the World Bank (WB) (Project Reference 0371-2012), for the financial support.

\section{References}

AB MAJID, A.H.; ZAHRAN, Z.; ABD RAHIM, A,B.; ISMAIL, N.A.; ABDUL RAHMAN, W.A.; ZUBAIRI, K.S.M.; DIENG, H.; SATHO, T. Morphological and molecular characterization of fungus isolated from tropical bed bugs in Northern Peninsular Malaysia, Cimex hemipterus (Hemiptera: Cimicidae). Asian Pacific Journal of Tropical Biomedicine, v.5, p.707-713, 2015. DOI: 10.1016/j.apjtb.2015.04.012.

ALGHUTHAYMI, M.A.; ALMOAMMAR, H.; RAI, M.; SAIDGALIEV, E.; ABD-ELSALAM, K.A. Myconanoparticles: synthesis and their role in phytopathogens management. Biotechnology and Biotechnological Equipment, v.29, p.221236, 2015. DOI: 10.1080/13102818.2015.1008194.

ANDERSEN, M.R.; NIELSEN, J.B.; KLITGAARD, A.; PETERSEN, L.M.; ZACHARIASEN, M.; HANSEN, T.J.; BLICHER, L.H.; GOTFREDSEN, C.H.; LARSEN, T.O.; NIELSEN, K.F.; MORTENSEN, U.H. Accurate prediction of secondary metabolite gene clusters in filamentous fungi. Proceedings of the National Academy of Sciences of the United States of America, v.110, p.99-107, 2013. DOI: 10.1073/ pnas. 1205532110 .

CLSI. Clinical and Laboratory Standards Institute. Performance standards for antimicrobial susceptibility testing; twentysecond informational supplement. Wayne: Clinical and Laboratory Standards Institute, 2012. (CLSI document M100 S22).

CODEX ALIMENTARIUS COMMISSION. Proposed draft code of practice for the prevention and reduction of ochratoxin $A$ contamination in cocoa. Rome: FAO, 2013. Joint FAO/WHO Food Standards of Programme. Available at: <ftp://ftp.fao.org/codex/ meetings/cccf/cccf7/cf07_09e.pdf>. Accessed on: May 102016.
COPETTI, M.V.; IAMANAKA, B.T.; PITT, J.I.; TANIWAKI, M.H. Fungi and mycotoxins in cocoa: from farm to chocolate. International Journal of Food Microbiology, v.178, p.13-20, 2014. DOI: 10.1016/j.ijfoodmicro.2014.02.023.

CUERVO-PARRA, J.A.; SÁNCHEZ-LÓPEZ, V.; RAMIREZSUERO, M.; RAMÍREZ-LEPE, M. Morphological and molecular characterization of Moniliophthora roreri causal agent of frosty pod rot of cocoa tree in Tabasco, México. Plant Pathology Journal, v.10, p.122-127, 2011. DOI: 10.3923/ppj.2011.122.127.

FAO. Food and Agriculture Organization of the United Nations. FAOSTAT. Available at: <http://www.fao.org/statistics/en/>. Accessed on: June 82012.

HANADA, R.E.; POMELLA, A.W.V.; SOBERANIS, W.; LOGUERCIO, L.L.; PEREIRA, J.O. Biocontrol potential of Trichoderma martiale against the black-pod disease (Phytophthora palmivora) of cacao. Biological Control, v.50, p.143-149, 2009. DOI: 10.1016/j.biocontrol.2009.04.005.

HARRIS, S.D. Morphogenesis in germinating Fusarium graminearum macroconidia. Mycologia, v.97, p.880-887, 2005. DOI: $10.3852 /$ mycologia.97.4.880.

KASPROWICZ, M.J.; KOZIOŁ, M.; GORCZYCA, A. The effect of silver nanoparticles on phytopathogenic spores of Fusarium culmorum. Canadian Journal of Microbiology, v.56, p.247-253, 2010. DOI: $10.1139 /$ w10-012

KIM, J.S.; KUK, E.; YU, K.N.; KIM, J.H.; PARK, S.J.; LEE H.J.; KIM, S.H.; PARK, Y.K.; PARK, Y.H.; HWANG, C.-Y.; KIM, Y.-K.; LEE, Y.-S.; JEONG, D.H.; CHO, M.-H. Antimicrobial effects of silver nanoparticles. Nanomedicine: Nanotechnology, Biology, and Medicine, v.3, p.95-101, 2007. DOI: 10.1016/j. nano.2006.12.001.

KRAUSS, U.; HOOPEN, M. TEN; REES, R.; STIRRUP, T.; ARGYlE, T.; GEORGE, A.; ARROYO, C.; CORRALES, E.; CASANOVES, F. Mycoparasitism by Clonostachys byssicola and Clonostachys rosea on Trichoderma spp. from cocoa (Theobroma cacao) and implication for the design of mixed biocontrol agents. Biological Control, v.67, p.317-327, 2013. DOI: 10.1016/j. biocontrol.2013.09.011.

KRISHNARAJ, C.; RAMACHANDRAN, R.; MOHAN, K.; KALAICHELVAN, P.T. Optimization for rapid synthesis of silver nanoparticles and its effect on phytopathogenic fungi. Spectrochimica Acta Part A: Molecular and Biomolecular Spectroscopy, v.93, p.95-99, 2012. DOI: 10.1016/j.saa.2012.03.002.

LAMSAL, K.; KIM, S.W.; JUNG, J.H.; KIM, Y.S.; KIM, Y.S.; LEE, Y.S. Application of silver nanoparticles for the control of Colletotrichum species in vitro and pepper anthracnose disease in field. Mycobiology, v.39, p.194-199, 2011. DOI: 10.5941/ MYCO.2011.39.3.194

MARTÍNEZ-ÁNGEL， J.; VILLAMIZAR-GALLARDO， R.; ORTÍZ-RODRÍGUEZ, O. Characterization and evaluation of cocoa (Theobroma cacao L.) pod husk as a renewable energy source. Agrociencia, v.49, p.329-345, 2015.

MBARGA, J.B.; BEGOUDE, B.A.D.; AMBANG, Z.; MEBOMA, M.; KUATE, J.; SCHIFFERS, B.; EWBANK, W.; DEDIEU, L.; HOOPEN, G.M. TEN. A new oil-based formulation of Trichoderma asperellum for the biological control of cacao black pod disease 
caused by Phytophthora megakarya. Biological Control, v.77, p.15-22, 2014. DOI: 10.1016/j.biocontrol.2014.06.004.

MONTEIRO, D.R.; GORUP, L.F.; SILVA, S.; NEGRI, M.; CAMARGO, E.R.; OLIVEIRA, R.; BARBOSA, D.B.; HENRIQUES, M. Silver colloidal nanoparticles: antifungal effect against adhered cells and biofilms of Candida albicans and Candida glabrata. Biofouling, v.27, p.711-719, 2011. DOI: 10.1080/08927014.2011.599101.

MORONES, J.R.; ELECHIGUERRA, J.L.; CAMACHO, A.; HOLT, K.; KOURI, J.B.; RAMÍREZ, J.T.; YACAMAN, M.J. The bactericidal effect of silver nanoparticles. Nanotechnology, v.16, p.2346-2353, 2005. DOI: 10.1088/0957-4484/16/10/059.

MOUNJOUENPOU, P.; GUEULE, D.; FONTANA-TACHON, A.; GUYOT, B.; TONDJE, P.R.; GUIRAUD, J.-P. Filamentous fungi producing ochratoxin A during cocoa processing in Cameroon. International Journal of Food Microbiology, v.121, p.234-241, 2008. DOI: 10.1016/j.ijfoodmicro.2007.11.017.

NASROLLAHI, A.; POURSHAMSIAN, K.; MANSOURKIAEE, P. Antifungal activity of silver nanoparticles on some of fungi. International Journal of Nano Dimension, v.1, p.233-239, 2011. DOI: 10.7508/ijnd.2010.03.007.

ORTIZ, O.O.; GALLARDO, R.A.V.; RANGEL, J.M. Applying life cycle management of Colombian cocoa production. Food Science and Technology, v.34, p.62-68, 2014. DOI: 10.1590/ S0101-20612014005000006.

ORTIZ-RODRIGUEZ, O.O.; NARANJO, C.A.; GARCÍACACERES, R.G.; VILLAMIZAR-GALLARDO, R.A. Water footprint assessment of the Colombian cocoa production. Revista Brasileira de Engenharia Agrícola e Ambiental, v.19, p.823-828, 2015. DOI: 10.1590/1807-1929/agriambi. v19n9p823-828.

PHILlIPS-MORA, W.; AIME, M.C.; WILKINSON, M.J. Biodiversity and biogeography of the cacao (Theobroma cacao) pathogen Moniliophthora roreri in tropical America. Plant Pathology, v.56, p.911-922, 2007. DOI: 10.1111/j.13653059.2007.01646.x.

PULIT, J.; BANACH, M.; SZCZGLOWSKA, R.; BRYK, M. Nanosilver against fungi. Silver nanoparticles as an effective biocidal factor. Acta Biochimica Polonica, v.60, p.795-798, 2013.

RANJAN, S.; DASGUPTA, N.; CHAKRABORTY, A.R.; SAMUEL, S.M.; RAMALINGAM, C.; SHANKER, R.; KUMAR, A. Nanoscience and nanotechnologies in food industries: opportunities and research trends. Journal of Nanoparticle Research, v.16, p.2464, 2014. DOI: 10.1007/s11051-014-2464-5.

SUÁREZ CONTRERAS, L.Y.; RANGEL RIAÑO, A.L. Aislamiento de microorganismos para control biológico de Moniliophthora roreri. Acta Agronómica, v.62, p.370-378, 2013.

VILLAMIZAR, R.A.; MAROTO, A.; RIUS, F.X. Rapid detection of Aspergillus flavus in rice using biofunctionalized carbon nanotube field effect transistors. Analytical and Bioanalytical Chemistry, v.399, p.119-126, 2011. DOI: 10.1007/s00216-0103975-2.

Received on August 9, 2015 and accepted on September 21, 2016

Pesq. agropec. bras., Brasília, v.51, n.12, p.1929-1936, dez. 2016

DOI: 10.1590/S0100-204X2016001200003 